\title{
Estimation of the dietary nutrient profile of free-roaming feral cats: possible implications for nutrition of domestic cats
}

\author{
Esther A. Plantinga ${ }^{1 *}$, Guido Bosch ${ }^{2}$ and Wouter H. Hendriks ${ }^{1,2}$ \\ ${ }^{1}$ Faculty of Veterinary Medicine, Utrecht University, PO Box 80.151, 3508 TD Utrecht, The Netherlands \\ ${ }^{2}$ Animal Nutrition Group, Wageningen University, PO Box 338, 6700 AH Wageningen, The Netherlands \\ (Received 22 October 2010 - Revised 25 February 2011 - Accepted 7 March 2011)
}

\section{Abstract}

Cats are strict carnivores and in the wild rely on a diet solely based on animal tissues to meet their specific and unique nutritional requirements. Although the feeding ecology of cats in the wild has been well documented in the literature, there is no information on the precise nutrient profile to which the cat's metabolism has adapted. The present study aimed to derive the dietary nutrient profile of free-living cats. Studies reporting the feeding habits of cats in the wild were reviewed and data on the nutrient composition of the consumed prey items obtained from the literature. Fifty-five studies reported feeding strategy data of cats in the wild. After specific exclusion criteria, twentyseven studies were used to derive thirty individual dietary nutrient profiles. The results show that feral cats are obligatory carnivores, with their daily energy intake from crude protein being $52 \%$, from crude fat $46 \%$ and from N-free extract only $2 \%$. Minerals and trace elements are consumed in relatively high concentrations compared with recommended allowances determined using empirical methods. The calculated nutrient profile may be considered the nutrient intake to which the cat's metabolic system has adapted. The present study provides insight into the nutritive, as well as possible non-nutritive aspects of a natural diet of whole prey for cats and provides novel ways to further improve feline diets to increase health and longevity.

Key words: Cats: Nutrient profile: Natural diet: Metabolism

The domestic cat (Felis silvestris catus) is adopted as a pet in millions of homes and can be considered one of the most popular pet animals worldwide. Cats were domesticated approximately 9000-10000 years ago in the Near East ${ }^{(1)}$ and are thought to originate from at least five distinctive subspecies of $F$. silvestris from across the Near East region, namely F.s. silvestris, F.s. lybica, F.s. ornate, F.s. cafra and F.s. bieti ${ }^{(1)}$. After domestication, descendants were dispersed across the world with human assistance, and gave rise to today's domestic cat. A small subset of these domesticated cats has undergone intensive selection directed at specific aesthetic traits, leading to the development of so-called pedigree cats. Nowadays, forty-one breeds are recognised by the Cat Fanciers' Association, including sixteen 'natural breeds ${ }^{(2)}$. These natural breeds are thought to be regional variants originating from domesticated $F$. silvestris subspecies ${ }^{(3)}$.

The initiation of domestication of wildcats is believed to have coincided with the change from the hunter-gatherer lifestyle of man in the Palaeolithic to the agricultural lifestyle in the Fertile Crescent about 12000 years ago ${ }^{(1,4)}$. The permanent human settlements stored grains and middens, providing a new ecological niche for commensal species such as mice and rats. These rodents became peridomestic and provided a reliable food source for native wildcats. Wildcats then became adapted to the urban environment and became commensals like rodents ${ }^{(5)}$. Wildcats in the urban environments were tolerated by people and, over time and space, gradually diverged from their 'wild' relatives by natural selection ${ }^{(6)}$.

Overall, the domestic cat genome organisation is remarkably conserved compared with the human genome, with cats displaying the fewest number of chromosomal changes relative to $\operatorname{man}^{(7,8)}$. Domestic cats also have retained a behavioural repertoire, for example, the ability to hunt effectively $^{(9)}$, which makes them very successful in the feral environment. The modern domestic cat still seems to largely resemble its wild ancestors genomically, morphologically and behaviourally. The formation of distinct breeds and the selection for breed-specific exterior traits over the past 50 years are unlikely to have resulted in major changes in the physiology and metabolism of certain breeds, as pedigree breeds are described as simple single-gene variants of natural breeds ${ }^{(10)}$.

Abbreviations: CP, crude protein; EE, ethereal extract; FMI, fresh matter intake; FO, frequency of occurrence; ME, metabolisable energy; NFE, N-free extract; PW, percentage of weight.

*Corresponding author: Dr Esther A. Plantinga, fax +31 30253 7970, email E.A.Plantinga@uu.nl 
The domestic cat's wild ancestors are known to be obligatory carnivores, consuming predominantly prey. The consumption of a diet composed of animal tissues throughout evolution has led to unique digestive and metabolic adaptations (often referred to as idiosyncrasies) ${ }^{(11-14)}$. Reduction of redundant enzymes and modification of enzyme activities will have had specific advantages in terms of energy expenditure $^{(11)}$. Examples of these adaptations include:

(a) The high dietary protein requirement as a consequence of a limited ability to decrease the enzyme activity of amino acid-catabolising enzymes below a certain threshold in response to a lowered protein intake ${ }^{(11)}$. The fact that other carnivorous animals, including fish and birds, have developed the same adaptations in protein metabolism ${ }^{(15-17)}$ indicates an advantage to carnivorous species in general.

(b) An inability for de novo arginine synthesis because of reduced activity of two enzymes in the intestinal pathway of citrulline synthesis (pyrroline-5-carboxylate synthase and ornithine aminotransferase) ${ }^{(11)}$.

(c) Two key enzymes in the pathway for taurine synthesis, namely cysteine dioxygenase and cysteinesulfinic acid decarboxylase, show low activities, thereby greatly reducing the endogenous synthesis of taurine and making this sulfonic amino acid an essential dietary nutrient for cats ${ }^{(11)}$. In addition, cats and dogs use taurine almost exclusively as a source for bile acid conjugation, unlike other animals, which can use glycine when taurine is limiting ${ }^{(11)}$.

(d) Cats are unable to use carotenoids to synthesise retinol because of a lack of carotene dioxygenase ${ }^{(11)}$.

(e) Synthesis of vitamin $\mathrm{D}_{3}$ is prevented by the high activity of 7-dehydrocholestrol reductase, an enzyme that reduces the availability of the precursor for 25-hydroxyvitamin $\mathrm{D}^{(18)}$.

(f) Cats are not able to synthesise niacin from tryptophan because of an extremely high activity of picolinic carboxylase. The activity of this enzyme is inversely related to niacin synthesis ${ }^{(11)}$.

(g) Cats have a limited ability to synthesise arachidonic acid from linoleic acid, attributed to a low activity of $\Delta-6$ and $\Delta$-8-desaturase ${ }^{(11,19)}$.

(h) Cats show several adaptations in the metabolism of starch and glucose, including a lack of salivary amylase activity, low activity of pancreatic and intestinal amylases $^{(20,21)}$, low hepatic glucokinase activity ${ }^{(22)}$, lack of hepatic fructokinase activity, necessary for metabolism of simple sugars $^{(21,23)}$ and a non-functional Tas1R2 receptor resulting in an inability to taste sugar ${ }^{(24)}$.

The above-mentioned adaptations are thought to have evolved from nutrition solely based on animal tissues and highlight the carnivorous nature of cats. Although the latter is well recognised, there is a paucity of information on the precise dietary nutrient profile responsible for these physiological and metabolic adaptations of the domestic cat. Many published studies have investigated the feeding habits of free-ranging cats and specified the dietary items consumed.
However, there is no information in the literature of the nutrient intake of cats from consumed dietary items.

The main objective of this literature study was to assess the nutrient profile to which the domestic cat's physiological and metabolic system has adapted. For this purpose, the feeding habits of feral cats (a free-ranging representative of the domesticated house cat) were reviewed and data on the nutrient composition of the different prey species were obtained from the literature. The nutrient profile (DM, crude protein (CP), ethereal extract (EE), N-free extract (NFE), ash, minerals and energy) of the diet of feral cats was calculated.

\section{Methods}

\section{Literature search and selection}

In the period from January to May 2010, electronic literature searches were conducted in Scopus and Web of Science to identify potentially eligible studies reporting diet compositions of free-roaming cats, as well as studies reporting whole-body nutrient composition of prey species consumed by cats. The literature search yielded fifty-five potentially eligible studies (Table 1). Eligibility of studies to include in the data analysis was based on four criteria. First, studies on feral cats were included whereas studies on the diet composition of wildcats were excluded. Second, for studies that used scat samples of cats for the assessment of diet composition, a criterion was set for the minimal number of collected scats samples. Trites \& Joy $^{(25)}$ stated that a minimal sample size of ninety-four scats is required when comparing diets to distinguish moderate effect sizes over time or between areas. These authors also state that collecting too few samples increases the likelihood of not finding a species in a scat sample that is consumed in low numbers and that dietary preference of a single individual becomes a larger part of the sampling error. Therefore studies with a scat sample size lower than ninety-four were not included in the present study. Third, for studies that used stomach and/or gut samples of cats for assessment of diet composition, the minimal number of collected samples was arbitrarily set at thirty per study. Fourth, to guarantee the 'wild' and 'human-independent' feeding behaviour of the cats, studies in which human-linked foods (for example, food scraps, anthropogenic refuse, human refuse, human garbage, rubbish) contributed more than $5 \%$ of the biomass consumed were not included. Based on these four criteria, twenty-eight studies were excluded (Table 1). The remaining twenty-seven eligible studies contained dietary information of feral cats based on 6666 stomach, gut and scat samples.

\section{Diet composition}

To standardise the comparison of results among studies, dietary item groups were created (see below) based on the information provided in the twenty-seven eligible studies. The category 'mammals' was split into subcategories 'rodents' (including rats, mice, voles, and other rodents), 'rabbits', 'insectivores' and 'other mammals'. 
WS British Journal of Nutrition

Table 1. Overview of the considered studies for inclusion in the calculations to determination the nutrient composition of feral cat diets

\begin{tabular}{|c|c|c|c|c|c|c|}
\hline Study no. & Reference & Location & Cat type & Material & Samples $(n)^{*}$ & Reason for exclusion \\
\hline 1 & Achterberg \& Metzger ${ }^{(50)}$ & Germany & Stray & Stomach, gut & 62 & Stray cat data \\
\hline 2 & Alterio \& Moller ${ }^{(81)}$ & South Island, New Zealand & Feral & Gut & 43 & \\
\hline 3 & Bayly $^{(31)}$ & South Australia & Feral & Stomach & 20 & $n<30$ \\
\hline 4 & Biró et al. ${ }^{(82)}$ & Hungary & Feral & Stomach, gut & 264 & \\
\hline 5 & Bloomer \& Bester ${ }^{(83)}$ & Marion Island, South Africa & Feral & Stomach & 587 & \\
\hline 6 & Bonnaud et al. ${ }^{(84)}$ & Port Cross Island, France & Feral & Scats & 386 & \\
\hline 7 & Borkenhagen ${ }^{(85)}$ & Germany & Stray & Stomach, gut & 189 & Stray cat data \\
\hline 8 & Brickner-Braun et al. & Israel & Stray & Stomach & 2531 & Stray cat data, human-linked foods $>5 \%$ \\
\hline 9 & Brooker $^{(87)}$ & Western Australia & Feral & Stomach & 8 & $n<30$ \\
\hline 10 & Campos et al. ${ }^{(88)}$ & South Eastern Brazil & Stray & Scats & 97 & Stray cat data, human-linked foods $>5 \%$ \\
\hline 11 & Catling $^{(30)}$ & New South Wales, Australia & Feral & Stomach & 112 & \\
\hline 12 & Clevenger ${ }^{(89)}$ & Balearic Islands, Spain & Feral & Scats & NP & Human-linked foods $>5 \%$ \\
\hline 13 & Coman \& Brunner ${ }^{(90)}$ & Victoria, Australia & Feral & Stomach & 80 & Human-linked foods $>5 \%$ \\
\hline 14 & Cook \& Yalden ${ }^{(91)}$ & Deserta Grande, Madeira, Portugal & Feral & Scats & 8 & $n<94$ \\
\hline 15 & Dilks $^{(92)}$ & Campbell Island, New Zealand & Feral & Scats & 20 & $n<94$ \\
\hline 16 & Fitzgerald et al. ${ }^{(93)}$ & Raoul Island, Madeira & Feral & Gut & 57 & \\
\hline 17 & Germain et al. ${ }^{(94)}$ & France & Feral & Stomach & 25 & $n<30$ \\
\hline 18 & Gil-Sanchez et al. ${ }^{(95)}$ & South East Spain & Wild & Scats & 189 & Data from wildcats \\
\hline 19 & Harper $^{(29)}$ & Stewart Island, New Zealand & Feral & Scats & 219 & \\
\hline 20 & Harper $^{(96)}$ & Port Ross, Auckland Island, New Zealand & Feral & Scats & 40 & $n<94$ \\
\hline 21 & Heidemann ${ }^{(97)}$ & North Germany & Stray & Stomach, gut & 145 & Stray cat data, human-linked foods $>5 \%$ \\
\hline 22 & Hutchings $^{(98)}$ & Victoria, Australia & Feral & Scats & 159 & $\%$ Human linked-foods $>5 \%$ \\
\hline \multirow[t]{3}{*}{23} & Jones \& Coman ${ }^{(80)}$ & Mallee, Victoria, Australia & Feral & Stomach, gut & 131 & \\
\hline & Jones \& Coman ${ }^{(80)}$ & Kinchega National Park, Australia & Feral & Stomach, gut & 65 & \\
\hline & Jones \& Coman ${ }^{(80)}$ & Eastern Highlands, Australia & Feral & Stomach, gut & 117 & \\
\hline 24 & Kirkpatrick \& Rauzon ${ }^{(99)}$ & Island Central Pacific Ocean, USA & Feral & Stomach & 78 & Data expressed in volume\% \\
\hline 25 & Langham $^{(100)}$ & Hawkes Bay, New Zealand & Feral & Scats & 361 & \\
\hline 26 & Liberg $^{(101)}$ & Southern Sweden & Feral & Scats & 1437 & Human-linked food $>5 \%$ \\
\hline 27 & Lüps ${ }^{(102)}$ & Canton Berne, Switzerland & Stray & Stomach & 83 & Stray cat data, human-linked foods $>5 \%$ \\
\hline 28 & Malo et al. ${ }^{(28)}$ & Central Spain & Wild & Scats & 239 & Wildcat data \\
\hline 29 & Martin et al. ${ }^{(103)}$ & Western Australia & Feral & Stomach & 93 & \\
\hline 32 & Matias \& Catry ${ }^{(104)}$ & Falkland Islands & Feral & Scats & 373 & \\
\hline 31 & Meckstroth et al. ${ }^{(105)}$ & South Bay, California, USA & Feral & Stomach & 68 & Human-linked foods $>5 \%$ \\
\hline 32 & Medina \& Nogales ${ }^{(106)}$ & Tenerife, Canary Islands, Spain & Feral & Scats & 477 & \\
\hline 33 & Medina et al. ${ }^{(107)}$ & La Palma, Canary Islands, Spain & Feral & Scats & 500 & \\
\hline 34 & Medina et al. (108) $^{-1}$ & Fuerteventura, Canary Islands, Spain & Feral & Scats & 209 & \\
\hline 35 & $\operatorname{Milan}^{(109)}$ & Majorca Island, Spain & Feral & Scats & 75 & $n<94$ \\
\hline 36 & Moleon \& Gil-Sanchez ${ }^{(110)}$ & South East Spain & Wild & Scats & 101 & Wildcat data \\
\hline 37 & Niewold ${ }^{(111)}$ & The Netherlands & Stray & Gut & 284 & Stray cat data, human-linked foods $>5 \%$ \\
\hline 38 & Nogales et al. ${ }^{(112)}$ & El Hierro, Canary Islands, Spain & Feral & Scats & 221 & \\
\hline 39 & Nogales et al. ${ }^{(113)}$ & Alegranze, Canary Islands, Spain & Feral & Scats & 110 & \\
\hline 40 & Nogales et al. ${ }^{(114)}$ & Tenerife, Canary Islands, Spain & Feral & Scats & 248 & \\
\hline 41 & Nogales \& Medina ${ }^{(115)}$ & La Gomera, Canary Islands, Spain & Feral & Scats & 135 & \\
\hline 42 & Paltridge et al. ${ }^{(16)}$ & Central Australia & Feral & Stomach & 336 & \\
\hline 43 & Peck et al. ${ }^{(117)}$ & Juan de Nova Island, Mozambique & Feral & Scats & 104 & \\
\hline 44 & Phillips et al. ${ }^{(118)}$ & San Clemente Island, California, USA & Feral & Scats & 602 & \\
\hline 45 & Pontier et al. ${ }^{(119)}$ & Grande Terre Island, Guadeloupe & Feral & Scats & 149 & \\
\hline 46 & Read \& Bowen ${ }^{(120)}$ & Roxby Downs, South Australia & Feral & Stomach & 316 & \\
\hline 47 & Risbey et al. ${ }^{(121)}$ & Western Australia & Feral & Gut & 109 & \\
\hline 48 & Santana et al. ${ }^{(122)}$ & Gran Canaria, Canary Islands, Spain & Feral & Scats & 133 & \\
\hline 49 & Sarmento $^{(123)}$ & Portugal & Feral & Scats & 220 & Wildcat data \\
\hline 50 & Snetsinger et al. ${ }^{(124)}$ & Mauna Kea, Hawaii, USA & Feral & Scats & 87 & $n<94$ \\
\hline
\end{tabular}


Twenty studies reported the percentage of weight (PW) for each consumed dietary item as part of the total biomass consumed by feral cats and these data were used as reported by in these studies. The remaining seven studies reported the frequency of occurrence (FO) of dietary items in stomach, gut and/or scat samples. Data reported as FO are generally considered to underestimate the importance of large prey and overestimate the importance of small prey ${ }^{(26)}$. For this reason, in the studies where data were reported as FO, the PW for each dietary item was calculated according to Fitzgerald \& $\operatorname{Karl}^{(27)}$ :

$$
\mathrm{PW}_{\text {prey } \mathrm{i}}=\frac{\mathrm{N}_{\text {prey } \mathrm{i}} \times \mathrm{BM}_{\text {prey } \mathrm{i}} \times 100}{\sum\left(\mathrm{N}_{\text {prey }} \times \mathrm{BM}_{\text {prey }}\right)}
$$

where $\mathrm{N}_{\text {prey }} \mathrm{i}$ is the number of individuals of prey $\mathrm{i}$ within all samples, $\mathrm{BM}_{\text {prey } \mathrm{i}}$ is the biomass of prey $\mathrm{i}$ obtained from the literature, and $\Sigma\left(\mathrm{N}_{\text {prey }} \times \mathrm{BM}_{\text {prey }}\right)$ was the total amount of biomass consumed. The biomass of identified prey groups was as follows: rats, $125 \mathrm{~g}^{(27)}$; mice, $15.5 \mathrm{~g}^{(27)}$; voles, $32.5 \mathrm{~g}^{(28)}$; unidentified rodents and insectivores, $50 \mathrm{~g}$ (estimated mean weight of rodents/insectivores, based on data from Malo et al $^{(28)}$, Fitzgerald \& $\operatorname{Karl}^{(27)}$ and Harper $\left.{ }^{(29)}\right)$; rabbits, $215 \mathrm{~g}$ (= calculated daily fresh matter intake (FMI), see below); birds, $50 \mathrm{~g}^{(29)}$; reptiles/amphibians, $3 \mathrm{~g}^{(28)}$; fish, $15 \mathrm{~g}^{(27)}$; invertebrates, $0.5 \mathrm{~g}^{(28)}$.

Although vegetation (i.e. plant material and seeds) is found in scat and stomach samples of cats, it usually represents a minor to negligible component of the diet on weight basis $^{(30-32)}$, and as a consequence was not taken into account in the calculations to PW.

\section{Nutrient composition of diet}

For the approximation of the nutrient composition of the diet consumed by the feral cats, the PW of each prey group was combined with compositional data of each of these groups. As these prey groups may contain several prey items, a mean value was calculated based on available data. Preferably compositional data of wild whole prey items were obtained from the literature (see Tables 3 and 4). No whole-body nutrient composition data were found in the literature for wild rats. Therefore data based on captive rats were used. Each separate study/diet composition (thirty in total) was used as an individual data point and all data were analysed with SPSS 16.0 for Windows (release 16.0.2; SPSS Inc., Chicago, IL, USA), using descriptive statistics.

\section{Calculation of dietary intake}

Daily FMI of cats was calculated based on estimated mean energy requirements for an average feral cat in a population. The energy requirement data for different age and reproductive classes were obtained from van Aarde et $a l .{ }^{(33)}$ and the percentage distributions of age and reproductive classes within a population of free-living feral cats were derived from Scott et $a l .{ }^{(34)}$. These data were combined to obtain a mean daily metabolisable energy (ME) requirement of $1258 \mathrm{~kJ}$ per cat. The estimated mean ME content of prey was 
calculated using modified Atwater factors ${ }^{(35)}$ with $3.5 \times \mathrm{CP}$, $8.5 \times \mathrm{EE}$ and $3.5 \times \mathrm{NFE}$. NFE was determined by difference as 100 - CP - EE - ash. The data are presented in Table 3. Daily FMI was calculated as the mean ME requirement divided by mean ME content of prey ( $585 \mathrm{~kJ} \mathrm{ME} / 100 \mathrm{~g}$ as is) resulting in $215 \mathrm{~g}$ fresh matter/feral cat per d. For prey items with a body weight exceeding the daily FMI, i.e. rabbits, the daily FMI was used instead of actual body weight for calculation of PW of that item to conform to the calculations by Fitzgerald $\& \operatorname{Karl}^{(27)}$.

\section{Results \\ Dietary profiles}

The twenty-seven articles included in the data analysis were carried out on four continents (North America, Europe, Africa and Australia) and included eighteen islands (Table 1). The dietary profiles of feral cats as reported in these twentyseven studies are reported in Table 2. The main items consumed by feral cats are mammals (78\%), followed by birds (16\%), reptiles/amphibians (3.7\%) and invertebrates $(1 \cdot 2 \%)$. Fish consumption is reported in three studies, and comprises of $0.3 \%$ of the items consumed. The consumption of plant material is reported in twenty-one studies, and fifteen studies reported consumption of human-linked food items, with one study (study 47 ) reporting an intake of $3.0 \%$ on a weight basis. Major mammals consumed are rabbits and rats although there is a large variation between studies. In one study (study 16), rats contributed $95 \cdot 8 \%$ to the total consumed biomass. On study sites where rabbits were abundantly present, they form a large proportion of the diet. On islands, the prey items consumed by feral cats differ markedly from that on the continents. Birds are an important part of the feral cat diet on islands where nesting sea birds are present. Marion Island (South Africa), an island with seabird colonies, nesting seabirds contribute to $81.3 \%$ (study 5) and $96.6 \%$ (study 55) to total biomass consumed (Table 2).

\section{Macronutrient composition prey items}

The whole-body macronutrient composition of different prey species obtained from various literature sources is shown in Table 3. Nutrients are expressed on a DM basis. The energy content is expressed as $\mathrm{kJ} \mathrm{ME} / 100 \mathrm{~g}$ DM. Energy contents of prey items varied reasonably, ranging from $1430 \mathrm{~kJ} / 100 \mathrm{~g} \mathrm{DM}$ for reptiles to $1917 \mathrm{~kJ} / 100 \mathrm{~g}$ DM for other mammals. DM contents of prey species ranged from $24 \cdot 8 \%$ (reptiles) to $34.7 \%$ (invertebrates). The $\mathrm{CP}$ content of prey items was relatively constant, ranging from $55.6 \% \mathrm{DM}$ for other mammals to $69.1 \%$ DM for fish. The proportion of EE varied more widely between prey items, ranging from $9.0 \%$ (reptiles) to $31.0 \%$ DM (other mammals). NFE content varied considerably between $0 \%$ (rats) and $12.9 \% \mathrm{DM}$ (invertebrates). The ash content of mammals was broadly similar, ranging from $9 \cdot 4 \%$ (rats) to $14.9 \% \mathrm{DM}$ (insectivores). The ash content of birds, reptiles, fish and invertebrates was 10.6, 15.2, $6 \cdot 8$ and $4.8 \%$ DM, respectively.

\section{Micronutrient and trace element composition of prey items}

The micronutrient and trace element compositions of the different prey items are given in Table 4 . The Ca concentration of vertebrate species ranged between 2.6 and $3.8 \% \mathrm{DM}$, while invertebrates contained only $0 \cdot 1 \% \mathrm{Ca}$ on a DM basis. The $\mathrm{P}$ content ranged from $1 \cdot 0$ (invertebrates) to $2 \cdot 7 \% \mathrm{DM}$ (voles). $\mathrm{Na}$ and $\mathrm{K}$ content showed a relatively wide variance, ranging from 0.35 (mice) to $0.83 \% \mathrm{DM}$ (other rodents) and 0.66 (birds) to $1.33 \% \mathrm{DM}$ (invertebrates), respectively. Mg content was fairly constant for most species, varying from $0 \cdot 10$ to $0 \cdot 16 \%$ $\mathrm{DM}$, with the exception of the $\mathrm{Mg}$ content in voles, which was only $0.04 \%$ DM. Fe, $\mathrm{Cu}$ and $\mathrm{Zn}$ content showed a wide variation between prey species, ranging from $7 \cdot 8$ (invertebrates) to $50 \cdot 0 \mathrm{mg} / 100 \mathrm{~g} \mathrm{DM}$ (insectivores), 0.74 (mice) to $12.24 \mathrm{mg} / 100 \mathrm{~g} \mathrm{DM}$ (reptiles/amphibians) and 8.6 (rabbits) to $25.7 \mathrm{mg} / 100 \mathrm{~g}$ DM (invertebrates), respectively.

\section{Nutrient profile}

Data presented in Tables 2 to 4 were used to calculate the nutrient profile of the natural diet of free-ranging feral cats. Fig. 1(a) displays the calculated macronutrient composition. The mean energy content of the natural diet was 1770 (SEM 13) $\mathrm{kJ} / 100 \mathrm{~g}$ DM, with the DM content being 30.5 (SEM 0.4 ) \%. The calculated mean macronutrient composition on a DM basis was 62.7 (SEM 0.30) \% CP, 22.8 (SEM 0.5) \% EE, 11.8 (sem $0 \cdot 1$ ) $\%$ ash and $2 \cdot 8$ (SEM $0 \cdot 3$ ) \% NFE. Fig. 1(b) shows the calculated micronutrient composition of the dietary profile of free-ranging feral cats, including the Ca:P ratio. A mean mineral content (in g/100g DM) of 2.64 (SEM 0.04) was found for $\mathrm{Ca}, 1.76$ (SEM 0.03) for P, 0.50 (SEM 0.01) for $\mathrm{Na}$, and 0.93 (SEM 0.01) for $\mathrm{K}$. The mean $\mathrm{Ca}: \mathrm{P}$ ratio was 1.51 (sEm 0.02). Trace element composition is shown in Fig. 1(c). The mean trace element content (in $\mathrm{mg} / 100 \mathrm{~g}$ DM) was 130 (sEm 4) for Mg, 29.6 (sem 1.1) for Fe, 1.67 (sEm 0.12) for $\mathrm{Cu}$ and $9 \cdot 77$ (sem $0 \cdot 19$ ) for $\mathrm{Zn}$.

\section{Discussion}

Knowledge about the feeding strategies, food items consumed and composition of the natural diet of man and animals provides valuable insights for the formulation and selection of appropriate diets to maintain health. The natural diet of humans has received much attention over the past decades $^{(36-41)}$ and has provided new information regarding the nutritional composition of the diet to which evolutionary forces adapted the core metabolism and physiology over a period of millions of years ${ }^{(36,40,42)}$. Frassetto et al. ${ }^{(39)}$ investigated whether a natural diet confers health benefits in human subjects and found that even short-term consumption of a Palaeolithic-type diet has proven health benefits for glucose metabolism and the cardiovascular system. In addition, the composition of breast milk has provided valuable information about the dietary nutrient profile to meet the nutrient requirement for optimal health and development of human infants ${ }^{(43)}$ For many captive, endangered and domesticated animal 
NS British Journal of Nutrition

Table 2. Data of dietary profiles of feral cats found in the literature (\% of weight)

Study no.*

\begin{tabular}{|c|c|c|c|c|c|c|c|c|c|c|c|c|c|c|c|c|c|}
\hline \multirow[b]{2}{*}{ Dietary item $\ddagger$} & \multirow[b]{2}{*}{2} & \multirow[b]{2}{*}{4} & \multirow[b]{2}{*}{5} & \multirow[b]{2}{*}{6} & \multirow[b]{2}{*}{11} & \multirow[b]{2}{*}{16} & \multirow[b]{2}{*}{19} & \multicolumn{3}{|c|}{$23 \dagger$} & \multirow[b]{2}{*}{25} & \multicolumn{2}{|c|}{$29 \dagger$} & \multirow[b]{2}{*}{30} & \multirow[b]{2}{*}{32} & \multirow[b]{2}{*}{33} & \multirow[b]{2}{*}{34} \\
\hline & & & & & & & & A & B & C & & A & B & & & & \\
\hline Mammals & 84.5 & $81 \cdot 0$ & 9.8 & $93 \cdot 1$ & $87 \cdot 2$ & $96 \cdot 7$ & 84.0 & $86 \cdot 7$ & $62 \cdot 3$ & 85.9 & $66 \cdot 9$ & 80.5 & $69 \cdot 6$ & $76 \cdot 0$ & 85.4 & $88 \cdot 3$ & 90.5 \\
\hline Rodents & 3.5 & $69 \cdot 3$ & 9.8 & $72 \cdot 1$ & - & 95.8 & 81.0 & $10 \cdot 7$ & 1.8 & 2.4 & $51 \cdot 3$ & $25 \cdot 0$ & 23.5 & $21 \cdot 0$ & $25 \cdot 7$ & $18 \cdot 1$ & 31.3 \\
\hline Rats & - & 4.3 & 9.8 & 69.8 & - & $95 \cdot 8$ & $81 \cdot 0$ & $2 \cdot 1$ & - & - & $39 \cdot 1$ & - & - & $17 \cdot 2$ & $12 \cdot 2$ & 14.5 & 9.1 \\
\hline Mice & 3.5 & $10 \cdot 3$ & - & - & - & - & - & 8.5 & 1.8 & $2 \cdot 4$ & $12 \cdot 2$ & - & - & 3.8 & 13.5 & 3.6 & $12 \cdot 6$ \\
\hline Voles & - & $51 \cdot 6$ & - & $2 \cdot 3$ & - & - & - & - & - & - & - & - & - & - & - & - & - \\
\hline Others rodents & - & $3 \cdot 1$ & - & - & - & - & - & - & - & - & - & $25 \cdot 0$ & 23.5 & - & - & - & $9 \cdot 6$ \\
\hline Rabbits & $70 \cdot 0$ & $8 \cdot 3$ & - & $21 \cdot 0$ & $82 \cdot 6$ & - & - & 74.3 & $56 \cdot 4$ & $43 \cdot 2$ & - & $53 \cdot 2$ & 34.3 & $55 \cdot 0$ & $59 \cdot 7$ & $70 \cdot 2$ & 57.8 \\
\hline Insectivores & 9.5 & 0.6 & - & - & - & - & - & - & - & - & - & - & - & - & - & - & 1.4 \\
\hline Other mammals & 1.5 & $2 \cdot 8$ & - & - & 4.6 & 0.9 & 3.0 & 1.7 & $4 \cdot 1$ & $40 \cdot 3$ & $12 \cdot 6$ & $2 \cdot 3$ & 11.8 & - & - & - & - \\
\hline Birds & $10 \cdot 0$ & $18 \cdot 7$ & $81 \cdot 3$ & 6.6 & $6 \cdot 6$ & $3 \cdot 1$ & $13 \cdot 0$ & 8.9 & $18 \cdot 2$ & $12 \cdot 9$ & $23 \cdot 9$ & $12 \cdot 9$ & 8.4 & $23 \cdot 3$ & 0.8 & 4.5 & 6.5 \\
\hline Reptiles/amphibians & 1.0 & 0.1 & - & 0.2 & 4.7 & - & $2 \cdot 0$ & 0.5 & $2 \cdot 1$ & 0.2 & - & 1.8 & $14 \cdot 1$ & - & $13 \cdot 6$ & $7 \cdot 1$ & $2 \cdot 0$ \\
\hline Invertebrates & $1 \cdot 0$ & + & - & + & 1.5 & 0.2 & $1 \cdot 0$ & 1.2 & 0.9 & 0.3 & 1.6 & $2 \cdot 6$ & 6.8 & - & + & 0.1 & $1 \cdot 1$ \\
\hline Fish & - & 0.2 & - & - & - & - & - & 0.7 & 9.5 & - & - & - & - & - & - & - & - \\
\hline Carrion & - & - & 8.9 & - & - & - & - & $2 \cdot 0$ & 6.9 & 0.7 & $7 \cdot 4$ & $2 \cdot 2$ & $1 \cdot 1$ & - & - & + & + \\
\hline Eggs & - & - & + & - & - & - & - & - & - & - & - & - & - & - & - & - & - \\
\hline Plant matter & + & + & + & - & - & + & - & + & + & + & - & + & + & 0.7 & + & + & + \\
\hline Human-linked foods & - & + & - & + & - & - & - & - & - & - & - & - & - & + & + & - & + \\
\hline Unidentified & 3.5 & - & - & - & - & - & - & - & - & - & 0.2 & - & - & - & - & - & - \\
\hline
\end{tabular}

Study no.*

\begin{tabular}{|c|c|c|c|c|c|c|c|c|c|c|c|c|c|c|c|}
\hline Dietary item $\ddagger$ & 38 & 39 & 40 & 41 & 42 & 43 & 44 & 45 & 46 & 47 & 48 & 52 & 55 & Mean & SEM \\
\hline Mammals & 85.4 & 77.5 & 99.5 & $89 \cdot 2$ & $90 \cdot 0$ & 74.5 & 83.5 & $85 \cdot 1$ & $72 \cdot 8$ & $92 \cdot 6$ & 89.4 & 54.0 & 1.8 & 77.5 & 4.0 \\
\hline Rodents & 14.3 & $12 \cdot 1$ & 8.0 & $70 \cdot 6$ & $90 \cdot 0$ & 74.5 & 83.5 & $11 \cdot 6$ & 5.4 & $4 \cdot 2$ & 5.9 & 33.0 & 1.8 & 31.9 & 5.8 \\
\hline Rats & $2 \cdot 8$ & 8.7 & - & $60 \cdot 9$ & + & 68.4 & $42 \cdot 9$ & - & - & - & $3 \cdot 3$ & $31 \cdot 0$ & - & $19 \cdot 1$ & $5 \cdot 2$ \\
\hline Mice & 11.5 & 3.4 & $8 \cdot 0$ & 9.7 & + & $6 \cdot 1$ & 30.7 & $11 \cdot 6$ & 5.4 & 4.2 & $2 \cdot 6$ & $2 \cdot 0$ & 1.8 & $5 \cdot 6$ & 1.2 \\
\hline Voles & - & - & - & - & - & - & - & - & - & - & - & - & - & 1.8 & $1 \cdot 7$ \\
\hline Others rodents & - & - & - & - & $90 \cdot 0$ & - & 9.9 & - & - & - & - & - & - & 5.4 & $3 \cdot 1$ \\
\hline Rabbits & $71 \cdot 1$ & 65.4 & 91.5 & $18 \cdot 6$ & + & - & - & $72 \cdot 6$ & 64.7 & 88.4 & 83.5 & - & - & 41.5 & $6 \cdot 0$ \\
\hline Insectivores & - & - & - & - & - & - & - & - & - & - & - & - & - & 0.4 & 0.3 \\
\hline Other mammals & - & - & - & - & - & - & - & 0.9 & $2 \cdot 7$ & - & - & $21 \cdot 0$ & - & 3.7 & 1.5 \\
\hline Birds & $8 \cdot 0$ & 1.5 & 0.3 & $4 \cdot 3$ & $6 \cdot 8$ & $25 \cdot 1$ & 8.8 & 14.9 & $18 \cdot 1$ & $2 \cdot 0$ & $3 \cdot 6$ & $30 \cdot 0$ & $96 \cdot 6$ & $16 \cdot 0$ & 3.9 \\
\hline Reptiles/amphibians & 5.9 & 20.9 & 0.1 & $6 \cdot 3$ & $2 \cdot 6$ & 0.2 & $5 \cdot 6$ & - & 8.3 & 0.9 & $6 \cdot 6$ & 3.0 & - & $3 \cdot 7$ & 0.9 \\
\hline Invertebrates & 0.8 & 0.1 & 0.1 & 0.2 & 0.6 & 0.2 & $2 \cdot 1$ & - & 0.8 & 1.2 & 0.2 & $12 \cdot 0$ & - & 1.2 & 0.4 \\
\hline Fish & - & - & - & - & - & - & - & - & - & - & - & - & - & 0.3 & 0.3 \\
\hline Carrion & + & - & - & - & - & - & - & - & - & 0.2 & - & + & 1.3 & 1.0 & 0.4 \\
\hline Eggs & - & - & - & - & - & - & - & - & - & - & - & - & - & + & + \\
\hline Plant matter & + & + & + & + & - & - & + & - & + & - & + & + & + & + & + \\
\hline Human-linked foods & + & + & + & + & - & + & - & - & + & $3 \cdot 0$ & + & - & - & 0.1 & 0.1 \\
\hline Unidentified & - & - & - & - & - & - & - & - & - & - & - & - & - & 0.1 & 0.1 \\
\hline
\end{tabular}

- , Food item was not mentioned; + , food item was present but not clearly quantified.

Data of studies 4, 5, 16, 43, 44, 46 and 55 were calculated from frequency of occurrence to percentage of weight as mentioned in the Methods section. Study numbers correspond to those in Table 1.

† Data of studies 23 and 29 were divided in subsets, as data were derived from different geographic locations (see also Table 1).

¥Large mammals ( $>5 \mathrm{~kg}$ body weight, i.e. sheep, cattle, kangaroos) were included within the 'carrion' category. Mammal, bird and reptile carrion was not quantified precisely and is included within the totals for each group. Cat fur, non-organic and unidentified materials were included within the 'unidentified' category. 
Table 3. Macronutrient composition of dietary ingredients of the feral cat diet

\begin{tabular}{|c|c|c|c|c|c|c|c|}
\hline \multirow[b]{2}{*}{ Dietary item } & \multirow[b]{2}{*}{ Energy (kJ ME/100 g DM) } & \multirow[b]{2}{*}{$\mathrm{DM}$ (\% as is) } & \multicolumn{4}{|c|}{ DM (\%) } & \multirow[b]{2}{*}{ References } \\
\hline & & & $\mathrm{CP}$ & $\mathrm{EE}$ & Ash & NFE & \\
\hline Rats & 1965 & 33.4 & $60 \cdot 1$ & 30.5 & $9 \cdot 4$ & 0.0 & $(128-131)$ \\
\hline Mice & 1812 & 33.1 & $59 \cdot 1$ & 24.5 & 11.3 & $5 \cdot 1$ & $(60,131-133)$ \\
\hline Voles & 1638 & 31.1 & 64.5 & $17 \cdot 2$ & $12 \cdot 7$ & $5 \cdot 6$ & $(60,132,134)$ \\
\hline Other rodents* & 1745 & $31 \cdot 1$ & 65.5 & $22 \cdot 1$ & $12 \cdot 4$ & 0.0 & $(60,132)$ \\
\hline Insectivores $†$ & 1644 & $31 \cdot 2$ & $61 \cdot 6$ & $19 \cdot 0$ & 14.9 & 4.5 & (132) \\
\hline Rabbits & 1748 & $26 \cdot 1$ & 63.9 & $22 \cdot 3$ & 12.5 & 1.3 & $(77,135)$ \\
\hline Other mammalsł & 1918 & 34.2 & $55 \cdot 6$ & 31.0 & 13.4 & 0.0 & (134) \\
\hline Birds§ & 1642 & 31.6 & $64 \cdot 6$ & $15 \cdot 9$ & $10 \cdot 6$ & 8.9 & $(134)$ \\
\hline Reptiles/amphibians\| & 1430 & $24 \cdot 8$ & $65 \cdot 7$ & 9.0 & $15 \cdot 2$ & $10 \cdot 1$ & $(77,78)$ \\
\hline Fish & 1870 & $25 \cdot 5$ & 69.1 & $24 \cdot 1$ & $6 \cdot 8$ & 0.0 & (136) \\
\hline Invertebrates ${ }^{\star *}$ & 1812 & 34.7 & $62 \cdot 3$ & 20.0 & 4.8 & 12.9 & $(44,134,137-139)$ \\
\hline
\end{tabular}

$\mathrm{ME}$, metabolisable energy; CP, crude protein; EE, ethereal extract; NFE, N-free extract (100 - CP - EE -ash).

${ }^{*}$ Derived from four different squirrel species.

†Derived from moles.

$\ddagger$ Derived from ten different species of bats and opossums.

§Derived from house sparrows.

|| Derived from two different species of reptiles, commonly eaten by cats.

I Derived from three different species of fish, commonly eaten by cats.

${ }^{\star *}$ Derived from seven different species of invertebrates, commonly eaten by cats.

species, the study of the natural diet has yielded data to successfully improve their nutrition ${ }^{(44-48)}$.

Here we report the nutrient profile of free-ranging feral cats using reported rates of ingestion of various dietary (prey) items in the literature. As expected, the results of the present study clearly show that feral cats are true carnivores, with the daily energy intake of feral cats from protein being $52 \%$, from fat $46 \%$ and from NFE only $2 \%$. Interestingly, a recent study by Hewson-Hughes et al. ${ }^{(49)}$ on voluntary macronutrient selection by adult domestic cats showed that when given the choice, adult cats select an intake target of about $420 \mathrm{~kJ} / \mathrm{d}$ from protein, about $280 \mathrm{~kJ} / \mathrm{d}$ from fat and about $100 \mathrm{~kJ} / \mathrm{d}$ from carbohydrate, representing $52 \%$ of daily energy intake from protein, $36 \%$ from fat and $12 \%$ from carbohydrate. These results are highly similar to the data presented here, indicating that cats appear to have developed, in addition to the above-mentioned metabolic adaptations, sensitive metabolic regulation mechanisms to consume an overall dietary macronutrient profile close to their evolutionary diet. The nutrient profile provides information to further enhance today's feline diets.

In the present study we used feral cats as a free-ranging model for domestic cats. Feral cats are described in the literature as cats which are descended from domestic cats, but are born and live without human contact and have survived in an ecosystem for many generations ${ }^{(50-52)}$. The domestic (feral) cat and wildcats are able to create fertile progeny ${ }^{(53)}$, which shows the close genetic resemblance between the wildcat population and domestic feral cats. Also, the behavioural repertoire of the feral cat to hunt effectively is remarkably conserved, with feral cats displaying similar hunting methods to wildcats ${ }^{(54)}$. The genetic variation between domestic and feral cats is negligible and metabolic adaptations are not likely to differ, making the feral cat a highly suitable free-roaming model for the domestic house cat.

Table 4. Micronutrient and trace element composition of dietary ingredients of the feral cat diet

\begin{tabular}{|c|c|c|c|c|c|c|c|c|c|}
\hline \multirow[b]{2}{*}{ Dietary item } & \multicolumn{5}{|c|}{ Content (g/100 g DM) } & \multicolumn{3}{|c|}{ Content (mg/100 g DM) } & \multirow[b]{2}{*}{ References } \\
\hline & $\mathrm{Ca}$ & $\mathrm{P}$ & $\mathrm{Na}$ & $\mathrm{K}$ & $\mathrm{Mg}$ & $\mathrm{Fe}$ & $\mathrm{Cu}$ & $\mathrm{Zn}$ & \\
\hline Rats & $2 \cdot 6$ & 1.5 & 0.50 & 1.03 & 0.11 & $18 \cdot 1$ & 0.78 & $7 \cdot 3$ & $(129-131)$ \\
\hline Mice & 2.9 & 1.7 & 0.35 & 1.00 & 0.11 & $23 \cdot 8$ & 0.74 & $12 \cdot 2$ & $(131,140,141)$ \\
\hline Voles & 2.9 & $2 \cdot 7$ & 0.43 & $1 \cdot 20$ & 0.04 & 33.2 & 1.37 & $10 \cdot 6$ & $(134)$ \\
\hline Other rodents* & 3.5 & 1.9 & 0.83 & 1.07 & 0.14 & $25 \cdot 3$ & 0.87 & $10 \cdot 2$ & (142) \\
\hline Insectivores† & 3.4 & 1.7 & 0.42 & 1.05 & 0.14 & $50 \cdot 0$ & $1 \cdot 18$ & $12 \cdot 0$ & $(140)$ \\
\hline Rabbits & $2 \cdot 4$ & 1.7 & 0.54 & 0.94 & 0.16 & $30 \cdot 2$ & 1.60 & $8 \cdot 6$ & $(77)$ \\
\hline Other mammals $\ddagger$ & $2 \cdot 8$ & 1.8 & 0.50 & 1.00 & 0.13 & $30 \cdot 2$ & $1 \cdot 18$ & $9 \cdot 8$ & $(77,129-131)$ \\
\hline Birds§ & $3 \cdot 0$ & $2 \cdot 1$ & 0.38 & 0.66 & 0.10 & 49.6 & $1 \cdot 26$ & 11.5 & $(131,143,144)$ \\
\hline Reptiles/amphibians\| & 3.8 & $2 \cdot 6$ & 0.50 & 0.95 & 0.15 & $17 \cdot 9$ & $12 \cdot 23$ & $19 \cdot 7$ & $(77,78)$ \\
\hline Invertebrates & 0.1 & $1 \cdot 0$ & 0.51 & $1 \cdot 33$ & 0.10 & $7 \cdot 8$ & $2 \cdot 21$ & $25 \cdot 7$ & $(134,137,138)$ \\
\hline
\end{tabular}

* Derived from fox squirrels.

$\dagger$ Derived from shrews.

¥Data from rats, mice, voles, other rodents, insectivores and rabbits pooled together.

§Data derived from five different bird species, commonly eaten by cats.

|| Data derived from two different species of reptiles, commonly eaten by cats.

I Data derived from two different species of invertebrates, commonly eaten by cats. 

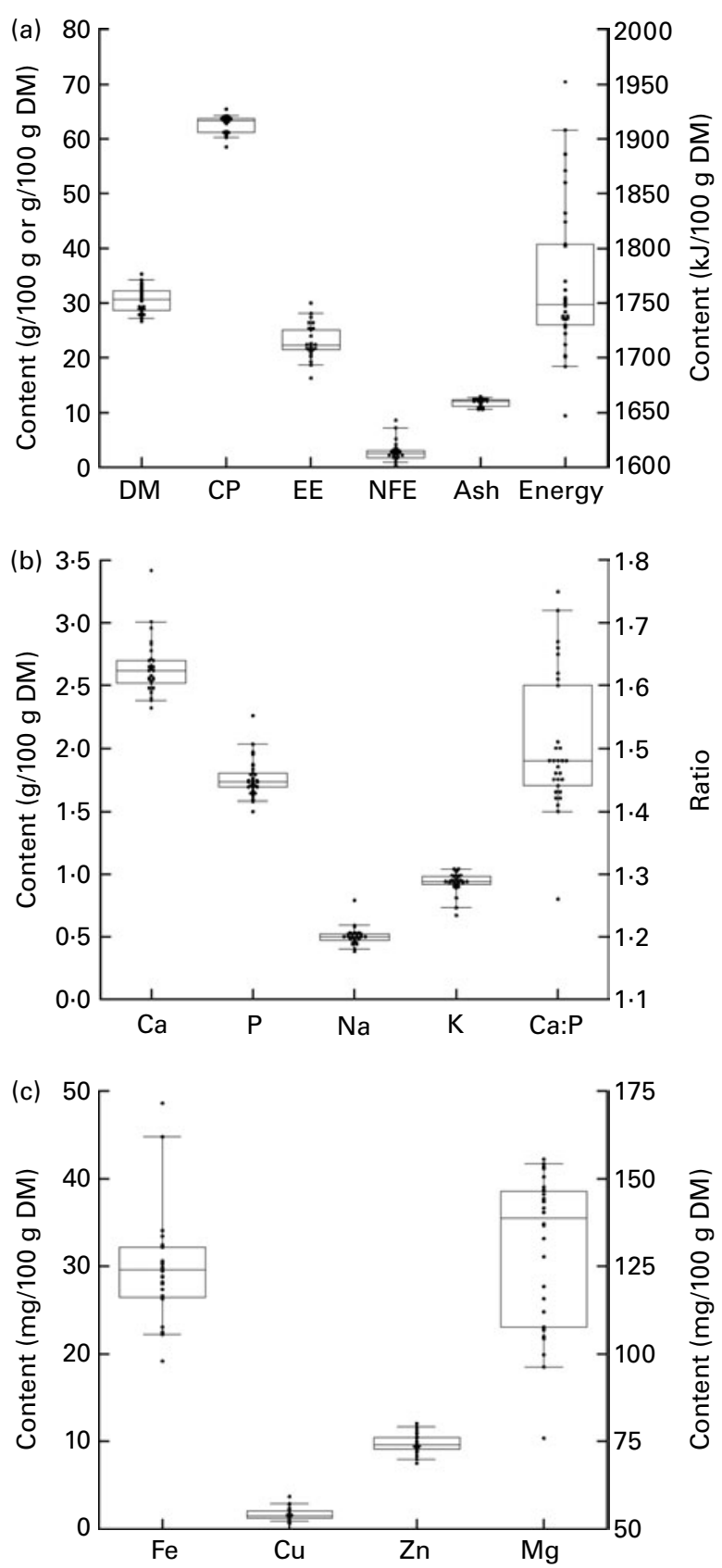

Fig. 1. (a) Calculated macronutrient composition of the natural diet of freeranging feral cats. $\mathrm{CP}$, crude protein; $\mathrm{EE}$, ethereal extract; NFE, N-free extract. The upper and lower hinges represent the 75th and 25th percentiles of the dataset. The band within the box represents the median. The whiskers extend to the $5 \%$ and $95 \% \mathrm{Cl}$. The calculated means are: DM, 30.5 (SEM 0.4) g/100 g; CP, 62.7 (SEM 0.3) g/100 g DM; EE, 22.8 (SEM 0.5) g/100 g DM; NFE, 2.8 (SEM 0.3) g/100 g DM; ash, 11.8 (SEM 0.1) g/100 g DM; energy, 1770 (SEM 13) kJ/100 g DM. (b) Calculated micronutrient composition of the natural diet of free-ranging feral cats. The upper and lower hinges represent the 75th and 25th percentiles of the dataset. The band within the box represents the median. The whiskers extend to the $5 \%$ and $95 \% \mathrm{Cl}$. The calculated means are: Ca, 2.64 (SEM 0.04) g/100 g DM; P, 1.76 (SEM 0.03) g/100 g $\mathrm{DM}$; Na, 0.50 (SEM 0.01) g/100 g DM; K, 0.93 (SEM 0.01) g/100 g DM; Ca:P, 1.51 (SEM 0.02). (c) Calculated trace element composition of the natural diet of free-ranging feral cats. The upper and lower hinges represent the 75 th and 25th percentiles of the dataset. The band within the box represents the median. The whiskers extend to the $5 \%$ and $95 \% \mathrm{Cl}$. The calculated means are: Fe, 29.59 (SEM 1.08) mg/100 g DM; Cu, 1.67 (SEM 0.12) mg/100 g DM Zn, 9.77 (SEM 0.19) mg/100 g DM; Mg, 130 (SEM 4) mg/100 g DM.
As described above, the cat's metabolism has adapted to a carnivorous lifestyle with many of the known adaptations relating to the protein, carbohydrate and vitamin component of the diet. Almost all the metabolic adaptations related to the carbohydrate component of the diet indicate the lack of this nutrient in the evolutionary diet. It could be argued that the shift from an obligatory meat-based natural diet to a meat-based and grain-based pet food rich in carbohydrates may place the cat's metabolism under stress, and might have unwanted negative health effects in the long run. Although dietary carbohydrate intake could not directly be determined in the present study, the NFE content was calculated. The fraction consists of components such as sugars, starches, monoand disaccharides, but also water-soluble vitamins. Animal tissue itself contains small amounts of glucose, glycogen, glycoproteins, glycolipid and pentose but does not contain starch. However, when consuming whole prey, the digesta of prey items may contain some starch. These carbohydrate sources may be the reason why cats have retained a limited ability to digest starch. The starch content of prey species is difficult to assess, as it is primarily based on the diet consumed. However, as an example, the following calculation provides an indication of the magnitude of starch ingestion by feral cats. The starch content of the digesta of captive young rabbits can be up to $130 \mathrm{~g} / \mathrm{kg} \mathrm{DM}$, depending on the starch source ${ }^{(55)}$. Assuming that the mean starch content of the digesta is approximately $100 \mathrm{~g} / \mathrm{kg}$ DM, digesta moisture content $80 \%^{(56)}$ and the digesta mass of rabbits $10 \%{ }^{(57)}$, the calculated starch content of a rabbit weighing $1.5 \mathrm{~kg}$ is $3.0 \mathrm{~g}$ ( $0.2 \%$ body weight). Wild rabbits forage primarily on grasses and leafy weeds, with high contents of fibre and relatively low contents of starch, making the latter a large overestimate. Prey species consumed by cats show considerable differences in digestive tract anatomy, with the digesta mass of rabbits being as high as $10 \%$ of body mass ${ }^{(57)}$, while omnivorous species such as the rat have a digesta mass of $0.5-2 \%$ of body weight ${ }^{(58)}$. The ability of cats to secrete pancreatic amylase may be beneficial in utilising the glycogen content of prey. Based on the above calculations, it can be concluded that the NFE content reported in the present study contains little starch and as such is composed of other fibrous material. Twenty-one of the twenty-seven studies reported small amounts of plant material being found in the scats, stomach and gut content of feral cats. Molsher et al. ${ }^{(59)}$ reported that cats frequently consume vegetation (FO of $26 \cdot 3 \%$ ) consisting mostly of a few strands of grass. The authors concluded, however, that plant material is a minor component of the diet of feral cats, as ingestion is likely to occur incidentally while foraging for invertebrates.

The physiological minimum nutrient requirements of cats for growth, maintenance and late gestation/peak lactation have been accurately determined ${ }^{(35)}$ and can be considered to represent the limit of the adaptation capacity of domestic cats in relation to dietary nutrient concentrations. Table 5 provides the minimum nutrient requirements and the recommended allowance of cats as provided by the National Research Council expressed in units/MJ ME. As can be seen from Table 5, there is a large difference between the 
Table 5. Recommended nutrient composition $v$. assessed nutrient composition of the 'natural' cat diet

\begin{tabular}{|c|c|c|c|c|c|c|c|}
\hline \multirow[b]{3}{*}{ Nutrient (MJ/ME) } & \multicolumn{6}{|c|}{ National Research Council( ${ }^{(35)}$} & \multirow{3}{*}{$\begin{array}{c}\text { Present study } \\
\text { Mean }\end{array}$} \\
\hline & \multicolumn{2}{|c|}{ Growth } & \multicolumn{2}{|c|}{ Maintenance } & \multicolumn{2}{|c|}{ Late gestation/peak lactation } & \\
\hline & Minimal & Recommended & Minimal & Recommended & Minimal & Recommended & \\
\hline Protein (g) & $10 \cdot 8$ & 13.5 & $9 \cdot 6$ & $12 \cdot 0$ & $10 \cdot 3$ & $12 \cdot 7$ & 35.4 \\
\hline Fat $(\mathrm{g})$ & - & $5 \cdot 4$ & - & 5.4 & - & $5 \cdot 4$ & $12 \cdot 9$ \\
\hline $\mathrm{Ca}(\mathrm{g})$ & 0.31 & 0.48 & 0.10 & 0.17 & 0.00 & 0.65 & 1.5 \\
\hline$P(g)$ & 0.29 & 0.43 & 0.08 & 0.15 & 0.29 & 0.45 & 1.0 \\
\hline K (g) & 0.16 & 0.24 & - & 0.31 & - & 0.31 & 0.53 \\
\hline $\mathrm{Na}(\mathrm{g})$ & 0.07 & 0.08 & 0.04 & 0.04 & 0.00 & 0.16 & 0.28 \\
\hline $\mathrm{Mg}(\mathrm{mg})$ & $9 \cdot 6$ & 23.9 & $12 \cdot 0$ & 23.9 & 24.9 & 29.9 & 73.4 \\
\hline $\mathrm{Fe}(\mathrm{mg})$ & $4 \cdot 1$ & 4.8 & - & 4.78 & - & 4.78 & $16 \cdot 7$ \\
\hline $\mathrm{Cu}(\mathrm{mg})$ & 0.26 & 0.50 & - & 0.29 & - & 0.53 & 0.9 \\
\hline $\mathrm{Zn}(\mathrm{mg})$ & 3.0 & 4.4 & 0.00 & 4.42 & 2.51 & 3.59 & 5.5 \\
\hline
\end{tabular}

ME, metabolisable energy.

recommended $\mathrm{CP}$ allowance and the $\mathrm{CP}$ content consumed by free-roaming feral cats. The data presented here on the evolutionary diet of cats do not include digestibility and bioavailability estimates of the different nutrients, making direct comparison with the recommended allowance more difficult. Estimates of macronutrient digestibility of whole prey items can be extrapolated from the literature on whole-prey assimilation by bobcats ${ }^{(60)}$ and ocelots ${ }^{(61)}$. In the study with bobcats, Powers et $a l .{ }^{(60)}$ evaluated the nutritive and energy value of winter diets of bobcats. Amongst others, a diet comprising of four species of rodents (mice and voles) was fed to four bobcats of wild origin. The apparent digestibility of CP and EE was 82.0 and $92.3 \%$, respectively. In the recent study by Bennett et $a l .{ }^{(61)}$, six diets (a commercial processed diet and five species of whole prey) were fed to a total of six ocelots to evaluate nutrient digestibility. The diets had similar digestibility values, with $\mathrm{CP}$ digestibility ranging from 85 to $91 \%$, and EE digestibility ranging from 96 to $99 \%$. The outcome of these studies makes the use of modified Atwater coefficients (in which protein and fat digestibility are estimated as 79 and $90 \%$, respectively ${ }^{(35)}$ ) for energy prediction of whole prey defendable but also the comparison of the recommended $\mathrm{CP}$ requirements of cats and the evolutionary $\mathrm{CP}$ intake. Data on bioavailability of micronutrients and trace elements in felids consuming whole prey items are lacking. Further research is needed to determine the precise nutrient digestibility of the natural diet, especially with respect to minerals such as $\mathrm{Ca}, \mathrm{P}, \mathrm{Mg}$ and $\mathrm{Fe}$, which are consumed in relatively high concentrations compared with recommended allowances determined using empirical methods. It is likely that the absorption of minerals such as $\mathrm{Ca}$ and $\mathrm{P}$ is much lower in prey items compared with the forms used to supplement commercial feline diets.

Information on the precise nutrient digestibility of the feral cat diet would allow conversion to a nutrient profile (and nutrient ratios) to which the cat's metabolism has been exposed during evolution. This nutrient profile originates from a cat population in which nutrition is a precondition for survival and procreation. In domestic cats, the nutritional goals may have gone beyond this, and are based on optimising health and longevity and as such may not be optimal. The median lifespan of a feral cat has been reported to be 4.7 years $^{(62)}$, while the domestic house cat has an average life expectancy of $12-14$ years ${ }^{(63)}$. Although such a nutrient profile may reflect the profile to which the cat's metabolic system has adapted, the question is whether it may be considered 'optimal' for today's nutritional goals in pet feeding. However, as stated earlier, valuable insights may be gained by an approach of studying the diet of feral cats. For example, the fatty acid composition is known to be influenced by the nutritional fatty acid intake in both humans and animals ${ }^{(64,65)}$ The fatty acid composition, especially the PUFA content and the $n-6: n-3$ ratio, differed considerably between wild or free-ranging animals and captive or feedlot animals. The $n-6: n-3$ ratios in captive or feedlot animals range between $6: 1$ to $19: 1^{(66-68)}$. It can be calculated that a diet based on wild animal species contains a ratio about $2: 1^{(66,67,69,70)}$. Domestic cats are fed commercially prepared foods containing lipids from captive domestic animal species and thus will consume a different fatty acid pattern compared with feral cats. For instance, the typical $n-6: n-3$ ratios in dog foods ranges between $5: 1$ to $17: 1^{(71)}$.

In addition to insights into the dietary nutrient intake, it is also important to note that non-nutritive properties, such as food consistency, texture, taste and temperature may play an important role in maintaining optimal health and function. Bond \& Lindberg ${ }^{(72)}$, in an investigation of the effect of feeding whole carcasses to captive cheetahs compared with feeding a commercial diet, concluded that feeding a more naturalistic diet may better meet a cheetah's physical, physiological and nutritional needs. In addition, feed consistency and texture have shown to be important in maintaining a balanced microbial population in the gastrointestinal tract in different animal species ${ }^{(73,74)}$. Moreover, consumption of whole prey provides for a relatively high intake of raw animal-derived fermentative substances, such as cartilage, collagen and glycosaminoglycans, which may enhance gut health, stimulate growth of a different subset of microbial commensals, and optimise immune function in a different way compared with 
consuming foods which are for a large part derived from plant origin and heat-treated.

Compositional data of prey species frequently preyed upon by feral cats are not abundantly available in the literature. For most mammals, data from wild-living animals could be obtained, with the exception of the rat. The rat data originate from captive rat species, which might explain the somewhat higher fat content compared with wild mice and voles $(30.5$ v. 24.5 and $17 \cdot 2 \% \mathrm{DM}$, respectively). Also, with regard to the micronutrient and trace element composition of the different prey species (Table 4), some interesting results were found. First, the Fe content of insectivores $(50.0 \mathrm{mg} / 100 \mathrm{~g}$ DM) and birds ( $49.6 \mathrm{mg} / 100 \mathrm{~g} \mathrm{DM})$ is nearly twice as high as for the other species. The group of insectivores includes soil-dwelling species, like moles and some shrews, which, because of their underground lifestyle, have undergone specific haematological changes. These changes include a higher serum Fe content, a higher $\mathrm{Hb}$ content, and a higher Fe-binding capacity of the blood ${ }^{(75)}$ and are thought to facilitate the uptake of $\mathrm{O}_{2}$ in an environment of reduced $\mathrm{O}_{2}$ and increased $\mathrm{CO}_{2}$ tension. The same is true for flying birds. Flying is one of the most $\mathrm{O}_{2}$-consuming activities, and facilitating $\mathrm{O}_{2}$ uptake through haematological changes enables flying birds to carry out this strenuous activity. Garcia et al. ${ }^{(76)}$ found that the Fe concentration per unit body weight of starling birds ranged from 153 to 185 parts per million, two to four times higher than values for mammals and non-flying birds. Second, the relatively high $\mathrm{Cu}$ and $\mathrm{Zn}$ contents for reptiles and amphibians may be overestimated. The reported values of both minerals in Carolina anoles $(35.3$ and $31.5 \mathrm{mg} / 100 \mathrm{~g}$ DM, respectively) by Dierenfeld et $a l .{ }^{(77)}$ differ considerably from those reported by Cosgrove et al. ${ }^{(78)}(0.5$ and $14.3 \mathrm{mg}$ / $100 \mathrm{~g} \mathrm{DM}$, respectively). The latter $\mathrm{Cu}$ and $\mathrm{Zn}$ contents of Carolina anoles are comparable and within the ranges of mammalian species (Table 4). Considering the finding that reptiles and amphibians only marginally contribute to the total energy intake of free-ranging feral cats (Table 2) and the fact that compositional data for reptiles and amphibians in literature are scarce, it was decided not to exclude the study of Dierenfeld et al. ${ }^{(77)}$. The relatively high $\mathrm{Cu}$ and $\mathrm{Zn}$ content of invertebrates is a normal pattern seen in many invertebrate species, both terrestrial and aquatic. Invertebrates are thought to be susceptible to accumulating heavy metals, especially $\mathrm{Cd}, \mathrm{Zn}$ and $\mathrm{Cu}^{(79)}$. Nevertheless, the nutrient composition of the different species provides an indication of the range of nutrient intakes of feral cats. Further compositional data of prey items consumed in conjunction with digestibility data would provide more robust estimates and ranges of the nutrient intake and metabolic exposure to nutrients of cats.

The methods used in the present study are open to criticism. The studies that were used to assess the dietary composition of feral cats used different methods (scats $v$. stomach content) and expressed their results in different ways (FO $v$. PW). These various ways of studying the diet and expressing results might produce biases that must be kept in mind. For example, identification of prey remains is more difficult in scat analysis than in analysis of stomach content. As a consequence, prey that was consumed in lesser amounts can more easily be overlooked when using scat analysis for dietary habit assessment. However, the major features of the diet of cats are thought to be sufficiently robust to be revealed despite the differences in methodology ${ }^{(26)}$. In addition, results expressed as FO were converted to PW to standardise the comparison of results. In these calculations assumptions needed to be made such as the mean weight for each prey item consumed, as described by Fitzgerald \& $\operatorname{Karl}^{(27)}$. For prey items with body weights exceeding the daily FMI, i.e. rabbits, the daily FMI (215g fresh matter) was used instead of actual body weight for calculation of PW. These calculations rely on the assumption that when a cat catches a rabbit, it consumes its full daily energy requirement in fresh matter (215 g). However, when a fasting cat catches a large prey item it may eat far more than $215 \mathrm{~g}$ of fresh matter. Jones \& Coman ${ }^{(80)}$ investigated the mean weights of rabbits eaten per meal by cats and calculated a mean FMI of 269-274g. This would imply that the contribution of rabbits to the dietary profile in the present study may be underestimated. On the other hand, a cat may eat less than $215 \mathrm{~g}$ of fresh matter if a larger part of its daily energy requirement is already met by the previous consumption of smaller prey items. In this situation the contribution of rabbits to the dietary profile may be underestimated. In the literature, a large variation is found in the assessment of daily FMI of free-ranging cats to calculate PW. Fitzgerald \& $\operatorname{Karl}^{(27)}$ estimated the daily maximum FMI within a cat population to be $170 \mathrm{~g}$, while, as previously mentioned, Jones et $a l{ }^{(80)}$ calculated the mean FMI for rabbits to be $269-274 \mathrm{~g}$. On average, the calculated daily FMI in the present study reflects the mean of the data range found in the literature. It should also be noted that most of the studies made year-round observations of the dietary habits of the feral cat, which means that seasonal fluctuation in nutrient intake were not taken into account. Also the studies used here for the calculation of the dietary nutrient profile of feral cats were carried out on different continents and islands, with the prey items consumed varying markedly between the different studies. For example, birds were a more important part of the feral cat diet on islands compared with continents (Table 2). These differences are probably related to latitude, climate and species diversity, and show that cats are general, opportunistic predators, exploiting a wide range of prey ${ }^{(26)}$. However, a dietary nutrient composition was developed from each individual study ( $n$ 30), and a mean (and standard error) nutrient composition calculated. The differences in prey profile between studies are thus reflected in the standard error, which is remarkably small for most nutrients. Overall, the approach taken in assessing the nutrient intake of feral cats can be criticised. However, the relatively large number of studies used (thirty data points from twenty-seven studies, yielding a total of 6666 samples) to calculate the nutrient intake, combined with the small range in nutrient composition between prey items makes the current estimates relatively robust.

\section{Conclusion}

The present study provides estimates of the gross nutrient intake of feral cats based on literature data of thirty different 
food consumption patterns. The calculated diet consists of $69.5 \%$ water, and contains $62.7 \% \mathrm{CP}, 22.8 \% \mathrm{EE}, 11.8 \%$ ash and $2.8 \%$ NFE on a DM basis. The starch content of the NFE fraction is low. The fatty acid profile consumed by feral cats has a ratio of $n-6: n-3$ in the order of $2: 1$, which differs from the ratio consumed by pet cats (ranging between 5:1 to 17:1). Additional data on specific prey item composition combined with estimates of the nutrient availability of prey items or a composite diet would provide more accuracy to derive a metabolic nutrient profile to which cats have adapted throughout evolution. Future research focus on the nutritive as well as non-nutritive value of consuming a natural diet of whole prey may gain valuable insights into how the nutrition of domestic cats can be further enhanced to increase health and longevity.

\section{Acknowledgements}

All authors contributed fundamentally to the present study. E. A. P. contributed to all facets, including research design, data collection, statistical analysis, interpretation and manuscript preparation. G. B. and W. H. H. contributed to research design, data interpretation and manuscript preparation.

The present study received no specific grant from a funding agency in the public, commercial or not-for-profit sectors, and therefore the present study is free of any conflicts of interest.

\section{References}

1. Driscoll CA, Menotti-Raymond M, Roca AL, et al. (2007) The Near Eastern origin of cat domestication. Science 317, 519-523.

2. Cat Fanciers' Association (1995) The Cat Fanciers' Association Cat Encyclopedia. New York: Simon \& Schuster.

3. Wastlhuber J (1991) History of domestic cats and cat breeds. In Feline Husbandry: Diseases and Management in the Multiple-Cat Environment, pp. 1-59 [NC Pederson, editor]. Goleta, CA: American Veterinary Publications.

4. Vigne JD, Guilaine J, Debue K, et al. (2004) Early taming of the cat in Cyprus. Science 304, 259.

5. Serpell JA (2000) The domestication and history of the cat. In The Domestic Cat. The Biology of its Behaviour, pp. 179-192 [DC Turner and P Bateson, editors]. Cambridge: Cambridge University Press.

6. Driscoll CA, Macdonald DW \& O'Brien SJ (2009) From wild animals to domestic pets, an evolutionary view of domestication. Proc Natl Acad Sci U S A 106, 9971-9978.

7. Murphy WJ, Sun S, Chen ZQ, et al. (2000) A radiation hybrid map of the cat genome: implications for comparative mapping. Genome Res 10, 691-702.

8. O'Brien SJ \& Yuhki N (1999) Comparative genome organization of the major histocompatibility complex: lessons from the Felidae. Immunol Rev 167, 133-144.

9. Bradshaw JWS (2006) The evolutionary basis for the feeding behavior of domestic dogs (Canis familiaris) and cats (Felis catus). J Nutr 136, 1927S-1931S.

10. Lipinski MJ, Froenicke L, Baysac KC, et al. (2008) The ascent of cat breeds: genetic evaluations of breeds and worldwide random-bred populations. Genomics 91, 12-21.

11. Morris JG (2002) Idiosyncratic nutrient requirements of cats appear to be diet-induced evolutionary adaptations. Nutr Res Rev 15, 153-168.
12. Macdonald ML, Rogers QR \& Morris JG (1984) Nutrition of the domestic cat, a mammalian carnivore. Annu Rev Nutr $\mathbf{4}$, 521-562.

13. Zoran DL (2002) The carnivore connection to nutrition in cats. J Am Vet Med Assoc 221, 1559-1567.

14. Zaghini $G$ \& Biagi $G$ (2005) Nutritional peculiarities and diet palatability in the cat. Vet Res Commun 29, 39-44.

15. Migliori Rh, Linder C, Moura JL, et al. (1973) Gluconeogenesis in a carnivorous bird (black vulture). Am J Physiol 225, 1389-1392.

16. Myers MR \& Klasing KC (1999) Low glucokinase activity and high rates of gluconeogenesis contribute to hyperglycemia in barn owls (Tyto alba) after a glucose challenge. J Nutr 129, 1896-1904.

17. Cowey CB, Cooke DJ, Matty AJ, et al. (1981) Effects of quantity and quality of dietary protein on certain enzyme activities in rainbow trout. $J$ Nutr 111, 336-345.

18. Morris JG (1999) Ineffective vitamin D synthesis in cats is reversed by an inhibitor of 7-dehydrocholestrol- $\Delta^{7}$ reductase. J Nutr 129, 903-908.

19. Macdonald ML, Anderson BC, Rogers QR, et al. (1983) Essential fatty acid requirements of cats: pathology of essential fatty acid deficiency. Am J Vet Res 45, 1310-1317.

20. Kienzle E (1993) Carbohydrate metabolism of the cat. 1. Activity of amylase in the gastrointestinal tract of the cat. J Anim Physiol Anim Nutr 69, 92-101.

21. Kienzle E (1993) Carbohydrate metabolism of the cat. 2. Digestion of starch. J Anim Physiol Anim Nutr 69, 102-114.

22. Washizu T, Tanaka A, Sako T, et al. (1999) Comparison of the activities of enzymes related to glycolysis and gluconeogenesis in the liver of dogs and cats. Res Vet Sci 67, 205-206.

23. Kienzle E (1994) Blood sugar levels and renal sugar excretion after intake of high carbohydrate diets in cats. J Nutr 124, 2563S-2567S.

24. Li X, Li W, Wang H, et al. (2005) Pseudogenization of a sweet-receptor gene accounts for cats' indifference toward sugar. PLoS Genet 1, 27-35.

25. Trites AW \& Joy R (2005) Dietary analysis from fecal samples: how many scats are enough? J Mammal 86 $704-712$.

26. Fitzgerald BM (1988) Diet of domestic cats and their impact on prey populations. In The Domestic Cat: The Biology of its Behaviour, pp. 123-147 [DC Turner and P Bateson, editors]. Cambridge: Cambridge University Press.

27. Fitzgerald BM \& Karl BJ (1979) Foods of feral house cats (Felis catus $\mathrm{L}$ ) in Forest of the Orongorongo Valley, Wellington. $N$ Z J Zool 6, 107-126.

28. Malo AF, Lozano J, Huertas DL, et al. (2004) A change of diet from rodents to rabbits (Oryctolagus cuniculus). Is the wildcat (Felis silvestris) a specialist predator? Zool $\mathbf{2 6 3}$ 401-407.

29. Harper GA (2004) Feral Cats on Stewart Island/Rakiura. DOC Science Internal Series no. 174. Wellington, New Zealand: Department of Conservation.

30. Catling PC (1988) Similarities and contrasts in the diets of foxes, Vulpes vulpes, and cats, Felis catus, relative to fluctuating prey populations and drought. Aust Wildl Res $\mathbf{1 5}$ 307-317.

31. Bayly CP (1978) A comparison of the diets of the red fox and the feral cat in an arid environment. $S$ Aust Nat $\mathbf{5 3}$ $20-28$.

32. Triggs B, Brunner H \& Cullen JM (1984) The food of fox, dog and cat in Croajingalon National Park, south-eastern Victoria. Aust Wildl Res 11, 491-499. 
33. van Aarde RJ (1980) The diet and feeding behavior of feral cats, Felis catus, at Marion Island. S Afr J Wildl Res $\mathbf{1 0}$ $123-128$.

34. Scott KC, Levy JK \& Crawford PC (2002) Characteristics of free-roaming cats evaluated in a trap-neuter-return program. J Am Vet Med Assoc 221, 1136-1138.

35. National Research Council (2006) Nutrient Requirements of Dogs and Cats. Washington, DC: The National Academies Press.

36. Eaton SB \& Konner M (1985) Paleolithic nutrition - a consideration of its nature and current implications. $N$ Engl J Med 312, 283-289.

37. Eaton SB, Eaton SB \& Konner MJ (1997) Paleolithic nutrition revisited: a twelve-year retrospective on its nature and implications. Eur J Clin Nutr 51, 207-216.

38. Eaton SB (2006) The ancestral human diet: what was it and should it be a paradigm for contemporary nutrition? Proc Nutr Soc 65, 1-6.

39. Frassetto LA, Schloetter M, Mietus-Synder M, et al. (2009) Metabolic and physiologic improvements from consuming a paleolithic, hunter-gatherer type diet. Eur J Clin Nutr 63, 947-955

40. Mann N (2000) Dietary lean red meat and human evolution Eur J Nutr 39, 71-79.

41. Strohle A \& Hahn A (2006) Evolutionary nutrition science and dietary recommendations of the Stone Age - the ideal answer to present-day nutritional questions or reason for criticism? Part 1, concept, arguments and paleoanthropological findings. Ernahrungs-Umschau 53, $10-16$.

42. Cordain L, Eaton SB, Sebastian A, et al. (2005) Origins and evolution of the Western diet: health implications for the 21st century. Am J Clin Nutr 81, 341-354.

43. Raiten DJ, Talbot JM \& Waters JH (1998) Assessment of nutrient requirements for infant formulas. J Nutr $\mathbf{1 2 8}$, 2059S-2293S.

44. Potter MA, Hendriks WH, Lentle RG, et al. (2010) An exploratory analysis of the suitability of diets fed to a flightless insectivore, the North Island brown kiwi (Apteryx mantelli), in New Zealand. Zoo Biol 29, 537-550.

45. Schley L \& Roper TJ (2003) Diet of wild boar Sus scrofa in Western Europe, with particular reference to consumption of agricultural crops. Mamm Rev 33, 43-56.

46. Brightsmith DJ, McDonald D, Matsafuji D, et al. (2010) Nutritional content of the diets of free-living scarlet macaw chicks in southeastern Peru. J Avian Med Surg 24, $9-23$.

47. Hendriks WH, O'Conner S, Thomas DV, et al. (2000) Nutrient composition of the crop contents of growing and adult grey-faced petrels (Pterodroma macroptera): a preliminary investigation. J Roy Soc New Zeal 30, 105-111.

48. Cottam Y, Merton D \& Hendriks WH (2006) Nutrient composition of the diet of parent-raised Kakapo nestlings. Norotnis 53, 90-99.

49. Hewson-Hughes AK, Miller AT, Hall SR, et al. (2011) Geometric analysis of macronutrient selection in the adult domestic cat, Felis catus. J Exp Biol 214, 1039-1051.

50. Achterberg H \& Metzger R (1980) Neue Untersuchungen und Erkentnisse zur Bedeutung der Hauskatze (Felis silvestris $f$. catus) für die Niederwildhege (New research and insights on the importance of the domestic cat (Felis silvestris $f$. catus) for lower game management). In Jahresschrift des Kreismuseums Haldensleben (Annual Publication of the Haldensleben Regional Museum), vol. 21, pp. 74-83, Kreismuseum Haldensleben.
51. Dickman C (1996) Overview of the Impact of Feral Cats on Australian Fauna. Canberra, Australia: Australian Nature Conservation Agency.

52. Pearre S \& Maass R (1998) Trends in the prey size-based trophic niches of feral and house cats Felis catus L. Mamm Rev 28, 125-139.

53. Pierpaoli M, Biro ZS, Herrmann M, et al. (2003) Genetic distinction of wildcat (Felis silvestris) populations in Europe, and hybridization with domestic cats in Hungary. Mol Ecol 12, 2585-2598.

54. Corbett LK (1979) Feeding ecology and social organisation of wild cats (Felis silvestris) and domestic cats (Felis catus) in Scotland. PhD Thesis, University of Aberdeen, Aberdeen.

55. Blas E \& Gidenne $\mathrm{T}$ (2010) Digestion of sugars and starch. In Nutrition of the Rabbit, pp. 19-38 [C de Blas and $\mathrm{J}$ Wiseman, editors]. Wallingford, UK: CABI Publishing.

56. Carabaño J, Piquer J, Menoyo D, et al. (2010) The digestive system of the rabbit. In Nutrition of the Rabbit, pp. 1-18 [C de Blas and J Wiseman, editors]. Wallingford, UK: CABI Publishing.

57. Livingston AE (1914) The relation of the gastro-intestinal tract and contents to the body weight in rabbits. $J$ Exp Med 19, 339-344.

58. Danielson AD, Newman RK, Newman CW, et al. (1997) Lipid levels and digesta viscosity of rats fed a high-fiber barley milling fraction. Nutr Res 17, 515-522.

59. Molsher R, Newsome A \& Dickman C (1999) Feeding ecology and population dynamics of the feral cat (Felis catus) in relation to the availability of prey in central-eastern New South Wales. Wildl Res 26, 593-607.

60. Powers JG, Mautz WW \& Pekins PJ (1989) Nutrient and energy assimilation of prey by bobcats. J Wildl Manage 53, 1004-1008

61. Bennett CL, Booth-Binczik SD \& Steele SRE (2010) Nutritional composition and digestibility by ocelots (Leopardus pardalis) of whole animals and a commercial diet. ZoO Biol 29, 753-759.

62. Levy JK, Gale DW \& Gale LA (2003) Evaluation of the effect of a long-term trap-neuter-return and adoption program on a free-roaming cat population. J Am Vet Med Assoc 222, 42-46.

63. Taylor EJ, Adams C \& Neville R (1995) Some nutritional aspects of ageing in dogs and cats. Proc Nutr Soc 54, 645-656.

64. Beynen AC, Hermus RJJ \& Hautvast JGAJ (1980) Mathematical relationship between the fatty acid composition of the diet and that of the adipose tissue in man. Am J Clin Nutr 33, 81-85.

65. Plantinga EA, Van Dijk N, Van Niel MHF, et al. (2003) Relationship between the amount of linoleic acid in the diet and that in the adipose tissue of adult cats living freely in households. Vet Res Commun 27, 603-610.

66. West GC \& Coady JW (1974) Fatty acid composition of tissue lipids of captive and wild brown lemmings. Comp Biochem Physiol 47, 353-368.

67. Rule DC, Broughton KS, Shellito SM, et al. (2002) Comparison of muscle fatty acid profiles and cholesterol concentrations of bison, beef cattle, elk, and chicken. J Anim Sci 80, 1202-1211.

68. Vicenti A, Ragni M, di Summa A, et al. (2003) Influence of feeds and rearing system on the productive performances and the chemical and fatty acid composition of hare meat. Food Sci Technol Int 9, 279-284.

69. Conway CJ, Eddleman WR \& Simpson KL (1994) Seasonal changes in fatty acid composition of the wood thrush. Condor 96, 791-794. 
70. Cobos A, Delahoz L, Cambero MI, et al. (1995) Chemical and fatty acid composition of meat from Spanish wild rabbits and hares. $Z$ Lebensm Unters Forsch 200, 182-185.

71. Ahlstrom O, Krogdahl A, Vhile SG, et al. (2004) Fatty acid composition in commercial dog foods. J Nutr 134, 2145S-2147S

72. Bond JC \& Lindburg DG (1990) Carcass feeding of captive cheetahs (Acinonyx jubatus): the effects of a naturalistic feeding program on oral health and psychological well-being. Appl Anim Behav Sci 26, 373-382.

73. Huang DS, Li DF, Xing JJ, et al. (2006) Effects of feed particle size and feed form on survival of Salmonella typhimurium in the alimentary tract and cecal S. typhimurium reduction in growing broilers. Poult Sci 85, 831-836.

74. Mikkelsen LL, Naughton PJ, Hedemann MS, et al. (2004) Effects of physical properties of feed on microbial ecology and survival of Salmonella enterica serovar Typhimurium in the pig gastrointestinal tract. Appl Environ Microbiol 70, 3485-3492.

75. Quilliam TA, Clarke JA \& Salsbury AJ (1971) The ecological significance of certain new haematological findings in the mole and hedgehog. Comp Biochem Physiol A Physiol 40, 89-94.

76. Garcia F, Ramis J \& Planas J (1984) Iron content in starlings, Stunus vulgaris L. Comp Biochem Physiol A Physiol 77, 651-654.

77. Dierenfeld ES, Alcorn HL \& Jacobsen KL (2002) Nutrient composition of whole vertebrate prey (excluding fish) fed in zoos. In AZA Nutrition Advisory Group Fact Sheet: A Review, pp. 1-20. Silverspring, MD: American Zoo and Aquarium Association.

78. Cosgrove JJ, Beermann DH, House WA, et al. (2002) Wholebody nutrient composition of various ages of captive-bred bearded dragons (Pogona vitteceps) and adult wild anoles (Anolis carolinensis). Zoo Biol 21, 489-497.

79. Boháč J \& Pospíšil J (1989) Accumulation of heavy metals in invertebrates and its ecological aspects. In Heavy Metals in the Environments, vol. I [JP Vernet, editor]. Edinburgh: CEP Consultants Ltd.

80. Jones E \& Coman BJ (1981) Ecology of the feral cat, Feliscatus (L), in Southeastern Australia. 1. Diet. Aust Wildl Res 8, 537-547.

81. Alterio N \& Moller H (1997) Diet of feral house cats Felis catus, ferrets Mustela furo and stoats $M$. erminea in grassland surrounding yellow-eyed penguin Megadyptes antipodes breeding areas, South Island, New Zealand. J Zool 243, 869-877.

82. Biro Z, Lanszki J, Szemethy L, et al. (2005) Feeding habits of feral domestic cats (Felis catus), wild cats (Felis silvestris) and their hybrids: trophic niche overlap among cat groups in Hungary. J Zool 266, 187-196.

83. Bloomer JP \& Bester MN (1990) Diet of a declining feral cat Felis catus population on Marion Island. S Afr J Wildl Res 20, 1-4.

84. Bonnaud E, Bourgeois K, Vidal E, et al. (2007) Feeding ecology of a feral cat population on a small Mediterranean island. J Mammal 88, 1074-1081.

85. Borkenhagen P (1979) Zur Nahrungsökologie streunender Hauskatzen (Felis sylvestris $f$. catus Linné, 1758) aus dem Stadtbereich Kiel (The feeding ecology of stray cats (Felis sylvestris $f$. catus Linnaeus, 1758) from the city area of Kiel). Z Saugetierk 44, 375-383.

86. Brickner-Braun I, Geffen E \& Yom-Tov Y (2007) The domestic cat as a predator of Israeli wildlife. Is $J$ Ecol Evol 53, 129-142.
87. Brooker MG (1977) Some notes on the mammalian fauna of the western Nullarbor Plain, Western Australia. West Aust Nat 14, 2-15.

88. Campos CB, Esteves CF, Ferraz KMPM, et al. (2007) Diet of free-ranging cats and dogs in a suburban and rural environment, south-eastern Brazil. J Zool 273, 14-20.

89. Clevenger AP (1995) Seasonality and relationships of food resource use of Martes martes, Genetta genetta and Felis catus in the Balearic Islands. Rev Ecol-Terre Vie 50, 109-131.

90. Coman BJ \& Brunner H (1972) Food habits of the feral house cat in Victoria. J Wildl Manage 36, 848-853.

91. Cook LM \& Yalden DW (1980) A note on the diet of feral cats in Deserta Grande. Bocagiana 52, 1-4.

92. Dilks PJ (1979) Observations on the food of feral cats on Campbell Island. $N$ Z J Ecol 2, 64-66.

93. Fitzgerald BM, Karl BJ \& Veitch CR (1991) The diet of feral cats (Felis catus) on Raoul Island, Kermadec Group. $N Z$ J Ecol 15, 123-129.

94. Germain E, Ruette S \& Poulle ML (2009) Likeness between the food habits of European wildcats, domestic cats and their hybrids in France. Mamm Biol 74, 412-417.

95. Gil-Sanchez JM, Valenzuela G \& Sanchez JF (1999) Iberian wild cat Felis silvestris tartessia predation on rabbit Oryctolagus cuniculus: functional response and age selection. Acta Theriol 44, 421-428.

96. Harper GA (2010) Diet of feral cats on subantarctic Auckland Island. $N Z J$ Ecol 34, 259-261.

97. Heidemann G (1973) Weitere Untersuchungen zur Nahrungsökologie 'wildernder' Hauskatzen (Felis sylvestris $f$. catus Linné, 1758) (Further studies on the feeding ecology 'wild Santander' house cats (Felis sylvestris $f$. catus Linnaeus, 1758)). Z Saugetierk 38, 216-224.

98. Hutchings $S$ (2003) The diet of feral house cats (Felis catus) at a regional rubbish tip, Victoria. Wildl Res 30, 103-110.

99. Kirkpatrick RD \& Rauzon MJ (1986) Foods of feral cats Felis catus on Jarvis and Howland Islands, Central Pacific Ocean. Biotropica 18, 72-75.

100. Langham NPE (1990) The diet of feral cats (Felis catus L) on Hawkes Bay farmland, New Zealand. $N Z J$ Zool 17, $243-255$.

101. Liberg O (1984) Food habits and prey impact by feral and house-based domestic cats in a rural area in southern Sweden. J Mammal 65, 424-432.

102. Lüps P (1972) Untersuchungen an streuenenden Hauskatzen im Kanton Bern (Investigations of stray domestic cats in Bern Canton). In Naturhistorisches Museum Bern, kleine Mitteilungen (National History Museum Bern, small release), vol. 4, pp. 1-8, Natural History Museum, Bern.

103. Martin GR, Twigg LE \& Robinson DJ (1996) Comparison of the diet of feral cats from rural and pastoral Western Australia. Wildl Res 23, 475-484.

104. Matias R \& Catry P (2008) The diet of feral cats at New Island, Falkland Islands, and impact on breeding seabirds. Polar Biol 31, 609-616.

105. Meckstroth AM, Miles AK \& Chandra S (2007) Diets of introduced predators using stable isotopes and stomach contents. J Wildl Manage 71, 2387-2392.

106. Medina FM \& Nogales M (1993) Dieta del gato cimarrón (Felis catus L.) en el piso basaldel Macizo de Teno (Noroeste de Tenerife) (Diet of the feral cat (Felis catus L.) on the base surface of Macizo de Teno (Noroeste de Tenerife)). Doňana Acta Vert 20, 291-297.

107. Medina FM \& Garcia R (2007) Predation of insects by feral cats (Felis silvestris catus L., 1758) on an oceanic island (La Palma, Canary Island). J Insect Conserv 11, 203-207. 
108. Medina FM, Lopez-Darias M, Nogales M, et al. (2008) Food habits of feral cats (Felis silvestris catus L.) in insular semiarid environments (Fuerteventura, Canary Islands). Wildl Res 35, 162-169.

109. Millan J (2010) Feeding habits of feral cats Felis silvestris catus in the countryside of Majorca Island, Spain. Wildl Biol Pract 6, 32-38.

110. Moleon M \& Gil-Sanchez JM (2003) Food habits of the wildcat (Felis silvestris) in a peculiar habitat: the Mediterranean high mountain. $J$ Zool 260, 17-22.

111. Niewold FJJ (1986) Voedselkeuze, terreingebruik en aantalsregulatie van in het veld opererendehuiskatten Felis catus L., 1758 (Food choice, land use and control of free ranging domestic cats Felis catus L. 1758). Lutra 29, $145-187$.

112. Nogales M, Martin A, Delgado G, et al. (1988) Food spectrum of the feral cat (Felis catus L. 1758) in the juniper woodlands on El Hierro (Canary Islands). Bonn Zool Beitr 39, $1-6$

113. Nogales M, Rodriguez JL, Delgado G, et al. (1992) The diet of feral cats (Felis catus) on Alegranza Island (North of Lanzarote, Canary-Islands). Folia Zool 41, 209-212.

114. Nogales M, Abdola M, Alonso C, et al. (1990) Premières donneés sur l'alimentation du chat haret (Felis catus L. 1758) du Parc National du Teide. Ténérife (Iles Canaries) (Initial data on the feeding of feral cats (Felis catus L., 1758) Teide National Park. Tenerife (Canary Islands)) Mammalia 54, 189-196.

115. Nogales M \& Medina FM (1996) A review of the diet of feral domestic cats (Felis silvestris $f$ catus) on the Canary Islands, with new data from the laurel forest of La Gomera. Z Saugetierk-Mamm Biol 61, 1-6.

116. Paltridge R, Gibson D \& Edwards G (1997) Diet of the feral cat (Felis catus) in central Australia. Wildl Res 24, 67-76.

117. Peck DR, Faulquier L, Pinet P, et al. (2008) Feral cat diet and impact on sooty terns at Juan de Nova Island, Mozambique Channel. Anim Conserv 11, 65-74.

118. Phillips RB, Winchell CS \& Schmidt RH (2007) Dietary overlap of an alien and native carnivore on San Clemente Island, California. J Mammal 88, 173-180.

119. Pontier D, Say L, Debias FO, et al. (2002) The diet of feral cats (Felis catus L.) at five sites on the Grande Terre, Kerguelen archipelago. Polar Biol 25, 833-837.

120. Read J \& Bowen Z (2001) Population dynamics, diet and aspects of the biology of feral cats and foxes in arid South Australia. Wildl Res 28, 195-203.

121. Risbey DA, Calver MC \& Short J (1999) The impact of cats and foxes on the small vertebrate fauna of Heirisson Prong, Western Australia. I. Exploring potential impact using diet analysis. Wildl Res 26, 621-630.

122. Santana F, Martin A \& Nogales M (1986) Datos sobre la alimentación del gato cimarrón (Felis catus Linneais, 1758) en los montes de Pajonales, Ojeda e Inagua (Gran Canaria) (Data on feeding feral cats (Felis catus Linneaus, 1758) in the mountains of Pajonales, Ojeda, and Inagua (Gran Canaria)). Vieraea 16, 113-117.

123. Sarmento P (1996) Feeding ecology of the European wildcat Felis silvestris in Portugal. Acta Theriol 41, 409-414.

124. Snetsinger TJ, Fancy SG, Simon JC, et al. (1994) Diets of owls and feral cats in Hawaii. 'Elepaio 54, 47-50.

125. Strong BW \& Low WA (1983) Some Observations of Feral Cats Felis Catus in the Southern Northern Territory. Technical report no. 9. Darwin: Conservation Commission of the Northern Territory.
126. Tidemann CR, Yorkston HD \& Russack AJ (1994) The diet of cats, Felis catus, on Christmas Island, Indian Ocean. Wildl Res 21, 279-286.

127. Tryjanowski P, Antczak M, Hromada M, et al. (2002) Winter feeding ecology of male and female European wildcats Felis silvestris in Slovakia. Z Jagdwissenschaft 48, 49-54.

128. Douglas TC, Pennino M \& Dierenfeld ES (1994) Vitamin E and $\mathrm{A}$, and proximate composition of whole mice and rats used as feed. Comp Biochem Physiol A Physiol 107, 419-424

129. Clum NJ, Fitzpatrick MP \& Dierenfeld ES (1996) Effects of diet on nutritional content of whole vertebrate prey. Zoo Biol 15, 525-537.

130. Clum NJ, Fitzpatrick MP \& Dierenfeld ES (1997) Nutrient content of five species of domestic animals commonly fed to captive raptors. J Raptor Res 31, 267-272.

131. Bird DM \& Ho SK (1976) Nutritive value of whole-animal diets for captive birds of prey. Raptor Res 10, 45-49.

132. Pitts GC \& Bullard TR (1968) Some interspecific aspects of body composition in mammals. In Body Composition in Animals and Man, pp. 45-70. Washington, DC: National Acadamy of Sciences.

133. Thomas J, Glatt B \& Dierenfeld ES (2004) Proximate, vitamins $\mathrm{A}$ and $\mathrm{E}$, and mineral composition of free-ranging cotton mice (Peromyscus gossypinus) from St. Catherines, Georgia. Zoo Biol 23, 253-261

134. Bird DM, Ho SK \& Pare D (1982) Nutritive values of 3 common prey items of the American kestrel. Comp Biochem Physiol A Physiol 73, 513-515.

135. Fortun-Lamoth L, Lamboley-Gaüzère C \& Bannelier C (2002) Prediction of body composition in rabbit females using total body electrical conductivity (TOBEC). Livestock Prod Sci 78, 133-142.

136. United States Department of Agriculture, Agricultural Reseach Service (2008) USDA National Nutrient Database for Standard Reference, release no. 21. Washington, DC: US Department of Agriculture.

137. Barker D, Fitzpatrick MP \& Dierenfeld ES (1998) Nutrient composition of selected whole invertebrates. Zoo Biol 17, 123-134.

138. Finke MD (2002) Complete nutrient composition of commercially raised invertebrates used as food for insectivores. Zoo Biol 21, 269-285

139. Donoghue $S$ (1998) Nutrition of pet amphibians and reptiles. Sem Avian Exotic Pet Med 7, 148-153.

140. Beyers RJ, Smith MH, Gentry JB, et al. (1971) Standing crops of elements and atomic ratios in a small mammal community. Acta Theriol 16, 203-211.

141. Kaufman DW \& Kaufman GA (1975) Prediction of elemental content in the old-field mouse. In Energy Research Administration Symposium Series no. 36, pp. 528-536 [FG Howell and JB Gentry, editors]. Springfield, Virginia: ERDA Symposium Series 36 (CONF-740513).

142. Havera S (1978) Nutrition, Supplemental Feeding, and Body Composition of the Fox Squirrel, Sciurus niger, in Central Illinois. Urbana-Champaign, IL: University of Illinois.

143. Grimshaw HM, Ovington JD, Betts MM, et al. (1958) The mineral content of birds and insects in plantations of Pinus silvestris L. Oikos 9, 26-34.

144. Skar HJ, Hagvar S, Hagen A, et al. (1975) Food habits and body composition of adult and juvenile meadow pipits [Anthus pratensis (L.)]. In Ecological Studies vol. 17, part 2, Fennoscandian Tundra Ecosystems, pp. 160-169 [FE Wielgolaski, editor]. New York: Springer-Verlag. 